\title{
The Behaviours of the Ukrainian Lending Rate, Deposit Rate, and Intermediation Premium
}

\author{
Chu V. Nguyen, Oksana Honcharenko
}

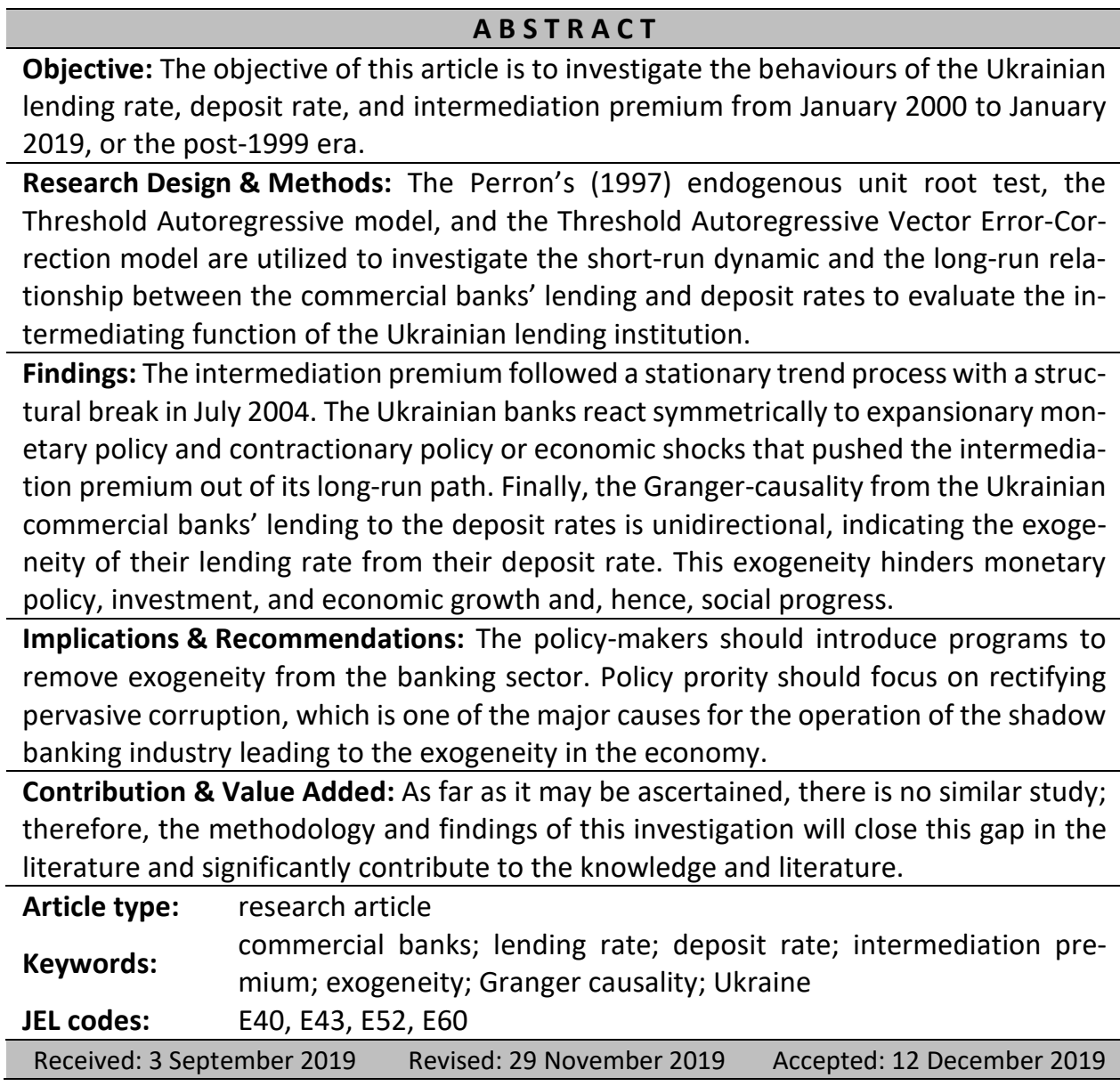

\section{Suggested citation:}

Nguyen, C.V., \& Honcharenko, O. (2020). The Behaviours of the Ukrainian Lending Rate, Deposit Rate, and Intermediation Premium. Entrepreneurial Business and Economics Review, 8(1), 143-158. https://doi.org/10.15678/EBER.2020.080108 


\section{INTRODUCTION}

Historically, theorists such as Schumpeter (1912), Patrick (1966), and McKinnon (1973) articulated that financial intermediation is a critical facilitator for investment and economic growth. By determining the spread between the lending rate and the cost of funds or the intermediation premium, commercial banks play a crucial role in the intermediation process. As argued by Nguyen (2015, p. 2), "In addition to creating interest income to financial intermediaries, the intermediation premium affects the economy's savings, investment and consumption levels and hence the effectiveness of the Central Banks' counter-cyclical monetary policies. Naturally, changes in consumption or investment would change employment, inflation and gross domestic product, which may affect economic development, and social progress."

It is not simple and automatic to channel funds from economic units with surpluses to economic units in need of funds to finance their profitable investment opportunities, even in advanced market economies that operate in transparent environment. This intermediation process depends on such factors as culture, financial and banking regulations, monetary policy, domestic and international political and economic conditions.

Ukraine was the second largest economy in the former USSR, producing four times the GDP of the distant third largest economy of Kazakhstan (CIA's World Factbook, 2019). The Ukrainian economy provided significant quantities of agricultural products such as meat, milk, grain, and vegetables, as opposed to manufactured goods. Ukrainian manufacturing segments consisted of heavy industrial equipment, such as large diameter pipes and vertical drilling apparatuses, while raw materials were supplied to industrial and mining sites of other republics in the former USSR. Unfortunately, since its independence on 24th of August, 1991, Ukraine has experienced severe political and economic turmoil. Currently, the Ukraine's oligarch-dominated economy is supported by significant inflows of remittances.

Based on the country's perceived corruption index score, the Heritage Foundation (2019) placed Ukraine 126th/182th in the 2019 country ranking. The Heritage Foundation further reports that the enforcement of contracts in Ukraine is time-consuming and costly. Furthermore, the judiciary is susceptible to political pressure, corruption, and bribery in most sectors of the economy. Consequently, public confidence in the legal system has waned. In this regard, Neutze and Karatnycky (2017, p. 11) articulate that "We concluded that only significant reduction in the levels of corruption will enable Ukraine to provide the sort of investment climate that would generate large and consistent flows of foreign capital, and prepare the country for its stated ambition of drawing closer to the European Union."

The Ukrainian economy in general, and the banking sector in particular, inherited problems from the collapse of the USSR. Therefore, market economic concepts - such as "competition", "cost", "credit", "deposit", "Investment", and "intermediaries" were not utilized or given much attention.

Given the aforementioned political and economic turmoil, and the importance of the intermediating function of commercial banks, the objective of this article is to evaluate the behaviours of the Ukrainian lending rate, deposit rate, and intermediation premium from January 2000 to January 2019. 
Methodologically, first part of our analysis searches for endogenous variables that account for the possible structural break in the long time series data, so as to avoid the possible misspecification of statistical models. Based on these results, we specify and estimate a Threshold Autoregressive (TAR) model and a Threshold Autoregressive Vector ErrorCorrection (TAR-VEC) model to scientifically and quantitatively investigate the behaviours of the Ukrainian lending rate, deposit rate, and intermediation premium. As far as we know, there is no such study. Therefore, the methodology and the findings of this investigation will close this gap in research and significantly contributes to the literature.

The following section provides a short review of literature and a brief characterization of the Ukrainian economy and the banking sector. Then comes a description of methodological issues and the specification of the model for investigation. The next section discusses the empirical results. The article ends with concluding remarks.

\section{LITERATURE REVIEW}

\section{Previous Studies}

From the economic theory perspective, Nguyen $(2015$, p. 2) argues that market forces are fairly predictable when it comes to how they react to very high and low spreads. In most cases, the market will adjust back to equilibrium spread behaviour in response to either very high or very low spreads. The three major hypotheses commonly used to explain the market equilibrium behaviour are bank concentration, the consumer characteristics, and the consumer reaction. According to several researchers, banks in concentrated or oligopoly markets are quick to raise lending rates when the central bank increases its discounts rates, and then slowly reduce the rates charge to borrowers in response to the drops in the central banks' discount rates (Hannan \& Berger, 1991; Neumark \& Sharpe, 1992). The consumer characteristics hypothesis views consumers as unsophisticated borrowers so lending institutions adjust rates to widen the spread and increase their profitability since borrower seem less sensitive to rate changes because of possible higher search and switching costs (Calem \& Mester, 1995; Hutchison, 1995; Rosen, 2002).

The consumer reaction hypothesis which is proposed by Payne and Water (2008, p. 1357) states that the customer reaction hypothesis suggests that banks are more sensitive to customers reactions if they operate in highly competitive environments, and fear strong negative reactions from customers to lending rate increases. This hypothesis supports the asymmetric adjustment of interest rates in a severe upward manner, which may create an adverse selection problem where higher interest rates attract riskier borrowers into the lending market (Stiglitz \& Weiss, 1981). Banks tend to respond cautiously in these situations by not quickly increasing lending rates, but may opt to ration credit in an attempt to minimize the default rates of riskier borrowers.

The foundation for hypothesizing the asymmetric adjustment process between the banks' lending rate and the cost of funds that lending institutions pay their depositors may be attributable to the seemingly opposite effect of the lending market and the countercyclical monetary policy over different phases of business cycles. More specifically, during the expansionary phases of business cycles, the stimulus of the counter-cyclical monetary policy would increase the money supply, leading to the lowering of banks' cost of funds, 
while the information from that state of the economy would precipitate the lending institutions to resist adjusting their spread between the lending rate and their cost of funds downward. This is based on the expected increase in the risky profiles of loan applicants. Consequently, the basis would increase or widen. By the same logic, we may argue that the spread between commercial banks' lending rates and their cost of funds would decrease or narrow during the contractionary phases of business cycles, while the cost of funds is increasing due to tight monetary policy (Nguyen, 2015).

Even though the interest rate asymmetry is relatively new topic, its literature is quite rich. Examples in the literature on emerging and advanced economies include, Dueker (2000) and Tkacz (2001), who report on the asymmetries in the US prime lending rate in the past. Thompson (2006) indicates asymmetries in the spread between US prime lending and deposit rate. Sarno and Thornton (2003) find asymmetries in the US Treasury securities. Scholnick (1999) shows asymmetries in mortgage rates in New Zealand and Canada. Hofmann and Mizen (2004) report on the asymmetric behaviour of retail rates in the UK.

Moreover, Lim (2001) applies the multivariate asymmetric error-correction model to Australian monthly data from the 1990:01-2000:04 sample period and reports that in response to positive and negative shocks - interest rate adjustments are asymmetric in the short run but not in the long run. Lim (2001) further posits that banks adjust their loan and deposit rates in response to a change in the bank-bill rate. They reported a faster rate during periods of monetary easing (negative changes) than during periods of monetary tightening (positive changes).

Several other studies find an asymmetric co-integration between bank lending and deposit rates. For instance, Nguyen, Pointer, and Smith (2008) report similar asymmetries in Mexican lending and deposit rates. Nguyen and Islam (2010) find asymmetries in Thai banks' lending and deposit rates. Nguyen and Henney (2013) indicate asymmetries in the US housing mortgage market. Chang and Su (2010) reveal nonlinear co-integration between lending and deposit rates in ten Eastern European countries.

More recently, Karagiannis, Panagopoulos, and Vlamis (2010) find symmetry in the adjustment of Greek retail rates in response to changes in the central bank's rate. In contrast, they found a negative asymmetry for Slovenia in the adjustment of loan and deposit rates in response to changes in the money market rate. As for Bulgaria, they report the negative asymmetry hypothesis in the adjustment of the rate of loans in response to changes in both the central bank and money market rates. Nguyen (2019a) finds that lending rates responded asymmetrically to changes in the Central Bank's policy related rates in the US, Chile, Jamaica, and Mexico, while the adjustments in Bolivia, Colombia, Costa Rica, and Honduras are symmetrical. As for transition economies, Nguyen (2019b) reports that - after being pushed out of their long-run paths by economic shocks or counter-cyclical monetary policy - the lending rates in the US, China, Hungary, Ukraine, and Vietnam adjusted asymmetrically, while the adjustment in Romania is symmetric.

\section{Ukrainian Banking Sector}

Today, Ukraine is unable to fulfil its internal financial obligations to regular Ukrainian citizens and service external debts without loans from the International Monetary Fund, the World Bank, other international financial institutions, and countries. 
The main problem is the "shadow" economy, which causes significant losses in the government's tax revenues. The tell-tale sign of Ukrainian economic problems is that aggregate consumption is twice as much as the reported income. Moreover, the prices of big-ticket commodities like real estate and automobiles are understated in the markets to avoid taxes. This situation arose due to high taxation on wages and corruption. The taxation problem grew in 2019 , when the government levied an $18 \%$ personal income tax, a $1.5 \%$ military tax, and a $22 \%$ corporate tax. Given these relatively high total tax rates and pervasive corruption aiding underground business activities to avoid taxes, a significant volume of the Ukrainian business transactions occur underground. Supposedly, the national budget also suffered from theft by various "programs." For example, exporters fabricated documents to receive refunds for portions of export taxes, which is a program introduced by the government to promote exports.

The Ukrainian banking industry first began its efforts at independent operations in 1988. By 1990, three of the five sectoral banks (Agroprombank, Promstroibank, and the Social Investment Bank) transformed into joint stock companies as Bank Ukraine, Prominvest, and Ukrsotsbank. By the time Ukraine declared its independence, the state owned banks accounted for most of the commercial banking business. During this same period, less than one hundred newly formed independent banks represented a much lower percentage of the country's banking industry (Sochan, 1998).

Sochan (1998) indicated that after the dissolution of the Soviet Union, the Ukrainian banking system formed as a natural entity to fill the void left after the State Bank of USSR no longer had authority in the country to perform banking transactions. State banks formally established under the soviet national banking systemwere liquidated, and the National Bank of Ukraine was formed as the central bank with a two tier system. Under this system the National Bank of Ukraine was the central banks and all newly formed banks would be responsible for performing the commercial banking transactions.

Since 2000, the development of the banking system of Ukraine is being restructured because of decreasing profitability, poor bank operations, and the consolidation of capital. One of the main indicators that characterizes the situation in the banking system of Ukraine is high base rate. This causes high levels of tax rate, which in turn leads to a rise in the interest rates on banks' loans to enterprises and the general population.

Given the aforementioned problems with the banking sector, and the Ukrainian "shadow" economy, this study investigates the behaviours of the Ukrainian lending rate, deposit rate, and intermediation by formulating and testing the following five research hypotheses:

H1: The Ukrainian intermediation premium is stationary with symmetric adjustments.

H2: The Ukrainian lending rate Granger causes the deposit rate in the short run.

H3: The Ukrainian deposit rate Granger causes the lending rate in the short run.

H4: The Ukrainian lending rate Granger causes the deposit rate in the long run.

H5: The Ukrainian deposit rate Granger causes the lending rate in the long run.

To test hypothesis 1, a Threshold Autoregressive model is specified and estimated, while a Threshold Autoregressive Vector Error-Correction model is formulated, estimated and the calculated test statistics are used to test hypotheses 2-5. Additionally, Nguyen and Kravchuk (2019, p. 195) articulated that economic shocks are common in most economies 
in the age of globalization. And, these shocks are expected to change relationships among long time series data, known as their affect structural breaks. Therefore, economic models should account for structural breaks to avoid possible misspecification of model. This study uses Perron's (1997) endogenous unit root tests to endogenously search for structural break in the data and if a break exists, a dummy variable would be introduced into the model specification processes to properly specify the models.

\section{MATERIAL AND METHODS}

\section{Structural Break}

To endogenously search for the possibility of any structural break in the commercial banks' lending rate-deposit rate spread, this study utilized Perron's (1997) endogenous unit root test function with the intercept, slope, and the trend dummy to test the hypothesis that the spread has a unit root.

$$
S P_{t}=\mu+\theta D U+\sigma \mathrm{t}+\gamma \mathrm{DT}+\delta \mathrm{D}\left(T_{b}\right)+\beta S P_{t-1}+\sum_{i=1}^{k} \psi_{i} \Delta \mathrm{SP}_{t-i}+v_{t}
$$

In which $S P_{t}$ is the spread between the commercial banks' lending rate $L R_{t}$ and the deposit rate, $D R_{t}$, or the intermediation premium; $D U=1\left(t>T_{b}\right)$ is a post-break constant dummy variable; $t$ is a linear time trend; $D T=1\left(t>T_{b}\right)$ is a post-break slope dummy variable; $D T\left(T_{b}\right)=1\left(t=T_{b}+1\right)$ is the break dummy variable; and $v_{t}$ is a white-noise error term. The null hypothesis of a unit root is stated as $\beta=1$. The break date, $T_{b}$, is selected based on the minimum t-statistic for testing $\beta=1$ (Perron, 1997).

\section{Threshold Autoregressive Model}

To specify the model for the empirical analysis, this study first follows Thompson (2006) to regress the spread, $S P_{t}$, on a constant, a linear trend, and an intercept dummy to formally examine the Ukrainian commercial banks' lending rates, the deposit rates, and their spread. The intercept dummy was assigned the value of zero prior to the structural break point and the value of one at the structural break point and thereafter.

$$
\mathrm{SP}_{t}=\phi_{0}+\phi_{1} \text { Trend }_{t}-\phi_{2} \text { Dummy }_{t}+\varepsilon_{t}
$$

In which $\mathrm{SP}_{t}$ is the Ukrainian lending-deposit rate spread, $\phi_{g}, \mathrm{~g}=0,1$, and 2 are coefficients to be estimated. The saved residuals from the above estimated model, denoted by $\hat{\varepsilon}_{t}$, are then used to estimate the following TAR model:

$$
\Delta \hat{\varepsilon}_{t}=I_{t} \rho_{1} \hat{\varepsilon}_{t-1}+\left(1-I_{t}\right) \rho_{2} \hat{\varepsilon}_{t-1}+\sum \alpha_{i} \Delta \hat{\varepsilon}_{t-p}+\hat{u}_{t}
$$

In which $a_{t} \sim$ i.i.d. $\left(0, \sigma^{2}\right), \Delta$ denotes the first difference of the variable, and the lagged values of $\Delta \hat{\varepsilon}_{t}$ are meant to yield uncorrelated residuals. As defined by Enders and Granger (1998), the Heaviside indicator function for the TAR specification is given as:

$$
I_{t}= \begin{cases}1 & \text { if } \hat{\varepsilon}_{t} \geq \tau \\ 0 & \text { if } \hat{\varepsilon}_{t}<\tau\end{cases}
$$

Nguyen $(2015$, p. 7$)$ indicates that, "The threshold value, $\tau$, is endogenously determined using Chan's (1993) procedure, which obtains $\tau$ by minimizing the sum of squared residuals after sorting the estimated residuals in ascending order and eliminating the largest and smallest $15 \%$ of values. The elimination of the largest and the smallest values assures the $\hat{\varepsilon}_{t}$ series crosses through the threshold in the sample period." 
Nguyen $(2015$, p. 7) further argues, the specification of this threshold autoregressive (TAR) model permits a degree of autoregressive decay to depend on the state of the commercial bank lending rate-deposit rate spread, i.e. the 'deepness' of cycles. As Nguyen (2015, p. 7) posits, the estimated TAR model empirically shows if the commercial bank lending ratedeposit rate spread tends to revert to the long-run position faster when the spread is above or below the threshold. Therefore, the TAR model reveals whether troughs or peaks persist more when shocks or counter-cyclical monetary policy actions push the commercial banks' lending rate-deposit rate spread out of its long-run equilibrium path. In this model, the null hypothesis that the commercial bank lending rate-deposit rate spread contains a unit root can be expressed as $\rho_{1}=\rho_{2}=0$, while the hypothesis that the spread is stationary with symmetric adjustments can be stated as $\rho_{1}=\rho_{2}$."

\section{Threshold Autoregressive Vector Error-Correction Model}

If the results of the tests on the above TAR model are positive, this study uses the following Threshold Autoregressive Vector Error-Correction model, specified by Equation (4), (5), and (6), to further investigate the asymmetric dynamic behaviour of the Ukrainian lending rate $\left(L R_{t}\right)$ and deposit rate $\left(D R_{t)}\right.$. By adding the $\Delta L R_{t-1}$ and $\Delta D R_{t-1}$ to Equation (5) and (6) to introduce short-run dynamics into the model, the resulting estimation can be used to study the nature of the Granger causality between the Ukrainian lending rates and deposit rates, short-run and long-term adjustments when the short-run dynamic adjustments are introduced. The statistical nature of the Granger causality will help to empirically evaluate whether and how the lending rates and the deposit rate respond to changes in the intermediation premium precipitated by counter-cyclical monetary policy or economic shocks.

$$
\begin{aligned}
& \Delta L R_{t}=\alpha_{0}+I_{t} \rho_{1} \hat{\varepsilon}_{t-1}+\left(1-I_{t}\right) \rho_{2} \hat{\varepsilon}_{t-1}+\sum_{i=1}^{n} \alpha_{i} \Delta L R_{t-i}+\sum_{i=1}^{n} \gamma_{i} \Delta L D_{t-i}+\hat{u}_{1, t} \\
& \Delta L D_{t}=\alpha_{0}+I_{t} \tilde{\rho}_{1} \hat{\varepsilon}_{t-1}+\left(1-I_{t}\right) \tilde{\rho}_{2} \hat{\varepsilon}_{t-1}+\sum_{i=1}^{n} \tilde{\alpha}_{i} \Delta L R_{t-i}+\sum_{i=1}^{n} \tilde{\gamma}_{i} \Delta L D_{t-i}+\hat{u}_{2, t}
\end{aligned}
$$

In which $\widehat{u}_{i, t} \sim$ i.i.d. $\left(0, \sigma^{2}\right), i=1,2$ and $I_{t}$ is set in accordance with Equation (4).

Moreover, as indicated by Thompson (2006), the above-specified TAR-VEC model differs from the convention error-correction models by allowing asymmetric adjustments toward the long-run equilibrium. Furthermore, the asymmetric error correctional model replaces the single symmetric error correction term with two error correction terms. Thus, besides estimating the long-run equilibrium relationship and asymmetric adjustment, the model allows for tests of short-run effects (dynamics) between changes in lending rate and deposit rate. In turn, the tests reveal the nature of the Granger causality.

\section{Data and Descriptive Statistics}

This study uses the monthly Ukrainian commercial banks' lending rates and deposit rates from January 2000 to January 2019 (2000:01-2019:01) when the data is available. These two time-series data were collected from the database maintained by the International Monetary Fund (IMF.) The IMF is one of the most reputable international financial institutions with its residential experts stationed in membered countries. Moreover, the IMF staff from Washington conduct annual consultations with membered countries. The quality of the economic and financial data provided by membered countries is one of the issues addressed in Article IV of the Annual Consultation Report, approved by the IMF's Board of Directors. Therefore, data extracted from an IMF's database is of high quality and hence very reliable. The commercial banks' lending rate, the deposit rate, and their spread are 
denoted by $L R_{t}, D R_{t}$, and $S P_{t}$, respectively. Figure 1 displays the behaviour of the commercial bank lending rate, the deposit rate and their spread over the sample period.

As illustrated in Figure 1, the Ukrainian lending rate and deposit rate generally tracked each other fairly well and were closer to each other, resulting in a stable lending-deposit rate spread. Over the sample period, the lending rate and deposit rate oscillate around steep downward trends until the middle of 2004 and then around slightly downward trends until the end of the sample period.

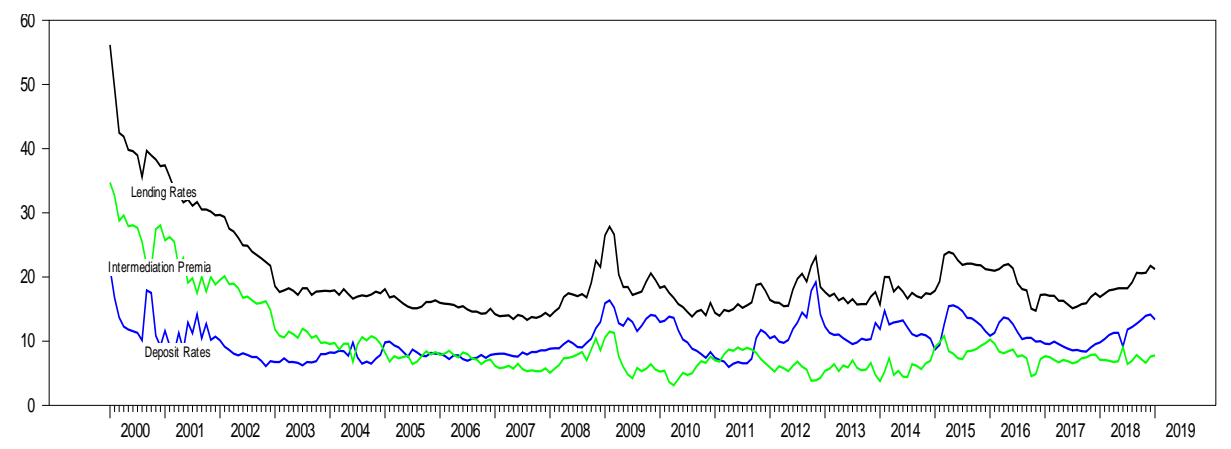

Figure 1. Ukrainian Lending Rates, Deposit Rates, and Intermediation Premia

Source: own calculation based on the monthly data extracted from the International Financial Statistics of the International Monetary Fund.

Moreover, descriptive statistical analysis reveals that the mean Ukrainian lending rate during the sample period was $19.96 \%$, and ranged from $13.31 \%$ to $56.19 \%$, with a standard deviation of $6.86 \%$. The mean deposit rate was $10.28 \%$, and ranged from $6.00 \%$ to $21.41 \%$, with a standard deviation of $2.75 \%$. Furthermore, the mean lending-deposit rate spread over the sample period was $9.68 \%$, and ranged from $3.12 \%$ to $34.78 \%$, with a standard deviation of $6.03 \%$. The correlation between the Ukrainian lending rate and the deposit rate is $48.31 \%$, which is very low. Numerically, for a given level of the lending rate, a monetary policy action or an economic shock causing the deposit rate to decrease would increase the lending-deposit rate spread. The opposite is true if the deposit rate were to change in the opposite direction. The low correlation between these two rates strongly suggests that one of the two rates is exogenous from or does not Granger cause the other rate, which may be discerned by the results of testing hypotheses 2-5.

\section{RESULTS AND DISCUSSION}

\section{Results of Perron's Test for Structural Break}

The estimation results of Perron's (1997) endogenous unit root tests are summarized in Table 1. The post-break intercept dummy variable, $D U$, is negative; the post-break slope dummy variable $D T$, is positive and they are both significant at the $1 \%$ level. The time trend is negative and is significant at the $1 \%$ level. The empirical results of these tests suggest that the Ukrainian commercial bank lending-deposit rate spread followed a stationary trend process with a break date on July 2004 , which may be attributed to the 
intervention in the foreign exchange market and monetary policy stimulations by the Central Bank from the beginning of 2004.

Table 1. Perron's Endogenous Unit Root Test, Ukrainian Data, January 2000 - January 2019

\begin{tabular}{|c|c|c|}
\hline $\begin{aligned} S P_{t}= & 7.38267-5.54140 D l \\
& \left(5.3619^{*}\right)\left(-5.0390^{*}\right)\end{aligned}$ & $\begin{array}{l}-0.10157 t+0.10195 \mathrm{DT}+ \\
\left(-4.7510^{*}\right) \quad\left(4.7598^{*}\right)\end{array}$ & $-1.66496 \mathrm{D}\left(T_{b}\right)+\underset{ }{\left.-1.6650^{* * *}\right)} \quad 0.72782 S P_{t-1}+v_{t}$ \\
\hline No. of augmented lags: $k=0$ & Break Date: July 2004 & $\mathrm{t}(\alpha=1)=-6.2238^{*}$ \\
\hline
\end{tabular}

Notes: Critical values for t-statistics in parentheses: Critical values based $n=100$ sample for the break-date (Perron, 1997).* and $* * *$ indicate significance at the $1 \%$ and the $10 \%$ levels Source: own calculation.

\section{Results of the Cointegration Test with Asymmetric Adjustment}

The estimation results of Equation (2) are reported in Table 2.

Table 2. Estimation Results, Eq. (2), Ukrainian Monthly Data, January 2000 - January 2019

\begin{tabular}{|c|c|c|}
\hline \multicolumn{4}{|c|}{$S P_{t}=\begin{array}{r}18.46461 \\
\left(35.1820^{*}\right)\end{array}$} & $\left(-2.6757^{*}\right) \quad\left(-10.9067^{*}\right)$ \\
\hline $\ln L=-624.2207 \bar{R}^{2}=0.6201$ & DW statistic & $(\mathrm{a})=0.1445$ \\
\hline
\end{tabular}

Notes: ${ }^{*}$ indicates significance at the $1 \%$ level. As articulated by Enders and Siklos (2001, p. 166), in this type of model specification, $\varepsilon_{\mathrm{t}}$ may be contemporaneously correlated Source: own calculation.

Given the estimation results of Equation (2), the estimation results of the TAR model are summarized in Table 3. An analysis of the overall estimation results indicates that the estimation results are devoid of serial correlation and have good predicting power, as evidenced by the Ljung-Box statistics and the overall F-statistics, respectively. The calculated statistic $\phi_{\mu}=8.7532$ indicates that the null hypothesis of no co-integration, $\rho_{1}=\rho_{2}=0$, should be rejected at the $1 \%$ significant level, confirming that the Ukrainian commercial banks' intermediation premium is stationary.

Table 3. Unit Root and Tests of Asymmetry, Monthly Data, January 2000 - January 2019

\begin{tabular}{|c|c|c|c|c|c|c|}
\hline$\rho_{1}$ & $\rho_{2}$ & $\tau$ & $H_{0}: \rho_{1}=\rho_{2}=0$ & $H_{0}: \rho_{1}=\rho_{2}$ & aic & sic \\
\hline$-0.1849^{*}$ & $-0.0994^{* *}$ & 0.7422 & $\phi_{\mu}=8.7532^{*}$ & $\mathrm{~F}=1.5054$ & 0.6235 & 0.6990 \\
\hline \multicolumn{2}{|c|}{$Q_{L B(12)}=12.0450(0.4421)$} & $\ln L=-387.8672$ & $F_{(4,222)}=5.6965^{*}$ & D.W. $=1.9832$ \\
\hline
\end{tabular}

Notes: The null hypothesis of a unit root, $H_{0}: \rho_{1=} \rho_{2=0}$, uses the critical values from Enders and Siklos (2001, p. 170 , Table 1 for four lagged changes and $n=100)$. " and ${ }^{* *}$ indicate the $1 \%$ and the $5 \%$ levels of significance. The null hypothesis of symmetry, $H_{0}: \rho_{1=} \rho_{2}$, uses the standard F distribution. $\tau$ is the threshold value determined via the Chan (1993) method. Q Q (12) denotes the Ljung-Box Q-statistic with 12 lags Source: own calculation.

The estimation results further reveal that both $\rho_{1}$ and $\rho_{2}$ are statistically significant at the $1 \%$ level. In fact, the point estimates suggest that the commercial bank lending ratedeposit rate spread tends to decay at the rate of $\left|\rho_{1}\right|=0.18486$ for $\hat{\varepsilon}_{t-1}$ above the threshold, $\tau=0.7422$ and at the rate of $\left|\rho_{2}\right|=0.09939$ for $\hat{\varepsilon}_{t-1}$ below the threshold. Numerically, 
the adjustments of the intermediation premium seem to be asymmetric; however, based on the estimated $F=1.5054$, the null hypothesis of symmetry, $\rho_{1=} \rho_{2}$, could not be rejected at any conventional significance level, indicating that adjustments around the threshold value of the commercial banks' intermediation premium are symmetric.

\section{Results of the Threshold Autoregressive Vector Error-Correction Model}

The estimation results of the Threshold Autoregressive Vector Error-Correction model are reported in Table 4 . In the summary of the estimation results, the partial $F_{i j}$ represents the calculated partial F-statistics, with the $p$-value in parentheses, testing the null hypothesis that all coefficients ij are equal to zero. ${ }^{*}$ indicates the $1 \%$ significant level of the t-statistics. $Q_{L B}(12)$ is the Ljung-Box statistics and its significance is in parentheses, testing for the first 12 of the residual autocorrelations to be jointly equal zero. $\ln L$ is the log likelihood. The overall F-statistic, with the $p$-value in parentheses, tests the overall fitness of the model. The retained estimated coefficients $\alpha_{i}, \gamma_{i}, \tilde{\alpha}_{i}$, and $\tilde{\gamma}_{i}$ are based on the $5 \%$ level of significance of the calculated $t$-statistics.

An analysis of the overall empirical results indicates that the estimated Equations (5) and (6) are devoid of serial correlation and have good predicting power as evidenced by the Ljung-Box statistics and the overall F-statistics, respectively. As to the short-run dynamic adjustment, the calculated partial F-statistics in Equations (5) and (6) indicate unidirectional Granger-causality from the Ukrainian lending rate to deposit rate.

Table 4. Asymmetric Error Correction Model, Monthly Data, January 2000 - January 2019

\begin{tabular}{|l|c|c|c|c|}
\hline \multirow{2}{*}{ Eq. (5) } & Overall $F_{(8,210)}=4.9014(0.0066) ; I n L=-335.2402 ; Q_{(12)}=4.9920(0.9582) ; \bar{R}^{2}=0.0603$ \\
\hline$\Delta L R t$ & $\alpha_{3}=\alpha_{5}=\alpha_{6}=\alpha_{9}=0$ & $\gamma_{1}=\gamma_{2}=0$ & $\rho_{1}$ & $\rho_{2}$ \\
\hline & Partial $F_{11}=4.5432(0.0015)$ & Partial $F_{12}=0.6090(0.5487)$ & -0.0556 & 0.0070 \\
\hline \multirow{2}{*}{ Eq. (6) } & Overall $F_{(6,208)}=5.8047(0.0000) ;$ InL=-319.8473; $Q_{(12)}=18.9220(0.0904) ;$ & $\bar{R}^{2}=0.1187$ \\
\hline \multirow{2}{*}{$\Delta D R t$} & $\tilde{\alpha}_{6}=\tilde{\alpha}_{13}=0$ & $\tilde{\gamma}_{1}=\tilde{\gamma}_{2}=0$ & $\tilde{\rho}_{1}$ & $\tilde{\rho}_{2}$ \\
\hline & Partial $F_{21}=9.7516(0.0000)$ & Partial $F_{22}=2.2674(0.1061)$ & $0.2325^{*}$ & -0.0004 \\
\hline
\end{tabular}

Notes: Partial F-statistics for lagged values of changes in the lending rate and deposit rate, respectively, are reported under the specified null hypotheses. $Q_{(12)}$ is the Ljung-Box Q-statistic to test for serial correlation up to 12 lags. *indicate the $1 \%$ level of significance; other levels of significance are in the parentheses Source: own calculation.

In addition to revealing the short-run dynamic Granger-causality, the asymmetric error correction model also allows the investigation of the long-run adjustments of the lending rate. Inconsistent with the empirical results of the TAR model, the estimation of Equation (5) indicated that $\left|\rho_{1}\right|>\left|\rho_{2}\right|$ when the short-run factors were incorporated in to the model. However, both $\rho_{1}$ and $\rho_{2}$ are insignificant at any conventional level. With regard to the long-run behaviour of the deposit rate, the estimation results for Equation (6) also show that $\left|\tilde{\rho}_{1}\right|>\left|\tilde{\rho}_{2}\right|$, after controlling for short-run factors; however, $\tilde{\rho}_{1}$ is significant at the $1 \%$ level, but $\tilde{\rho}_{2}$ is statistically insignificant even at the $10 \%$ level. 


\section{DISCUSSION}

This investigation used monthly time-series data maintained by the International Monetary Fund over the January 2000 through January 2019 period where the data is available to study how Ukrainian commercial banks set changes in deposit rate that might be precipitated by changes in Central Bank's counter-cyclical monetary policy measures or economic shocks. Descriptive statistics indicated that commercial banks' lending rate, deposit rate, and intermediation premium were very high compared to reported figures for other transitional economies (Nguyen, 2015; Nguyen, Phan, \& Williams, 2017; Nguyen, 2018; Nguyen, 2019b). As Figure 1 indicates, over the sample period, the lending rate and deposit rate oscillated around steep downward trends until the middle of 2004 and then around slightly downward trends until the end of the sample period.

Perron's endogenous unit root tests confirmed that the Ukrainian commercial banks' lending-deposit rate spread followed a stationary trend process with a break date of July 2004, which may be attributed to the stimulating monetary policy in the first six months of 2004. More specifically, in their efforts to increase economic growth, the Ukrainian Central Bank intervened into the foreign exchange market. Along with an animation of privatization processes, the Central Bank tried to increase the foreign currency reserves by purchasing international currencies in the interbank market. As a result, during the first nine months of the year, the monetary base grew by $38.2 \%$, compared to $24.3 \%$ in the same period in 2003 . During this period, the money supply rose by $37.1 \%$, while the corresponding figure for the same period in 2003 was 33.3\% (National Bank of Ukraine, 2005).

As to the nature of the relationship between the commercial banks' lending rate and deposit rate, the estimation results for Equation (3) suggested that the null hypothesis of symmetry, $\rho_{1}=\rho_{2}$, could not be rejected at any conventional level of significance. Failure to reject this null hypothesis indicates that adjustments around the threshold value of the commercial banks' intermediation premium are symmetric, which also means failure to reject hypothesis 1 . This finding suggests that the Ukrainian lending institutions would respond to the expansionary policy measures or economic shocks in the same fashion as they do with regard to contractionary monetary policy measures.

With regard to time lags in term of months of adjustments, the empirical results for Equations (5) and (6) coincidentally revealed that the longest time lags for $\alpha_{i}$ is nine months and $\gamma_{i}$ is two months; while those for $\tilde{\alpha}_{i}$, and $\tilde{\gamma}_{i}$ are thirteen and two months, respectively. Moreover, the partial F-statistics, in Table $4, F_{11}$ and $F_{21}$ are significant while $F_{12}$ and $F_{22}$ are not significant. Behaviourally, the insignificance of $F_{12}$ indicates that the null hypothesis $H 3$ should be rejected, i.e. the Ukrainian deposit rate does not Granger cause the lending rate in the short run. However, the significance if $F_{21}$ suggests that the null hypothesis $H 2$ cannot be rejected, i.e. the Ukrainian lending rate does Granger cause the deposit rate in the short run.

These aforementioned hypothesis testing results revealed the unidirectional Granger causality from lending rate to deposit rate over the sample period. These findings suggested that changes in the lending rate affected the deposit rate, but the deposit rate was exogenous from the lending rate. These empirical results also suggested that Ukrainian-lending institutions look at their lending rates in the past nine months $\left(\alpha_{i}=9\right)$, but not deposit rates to set their current lending rate. Moreover, as indicated by $\tilde{\alpha}_{i}=13$, after a change in the 
lending rate pushing the intermediation premium out of its long-run path, the Ukrainian lending institutions took up to 13 months to adjust the deposit rate to the new equilibrium.

Furthermore, the estimation results for Equation (5) - revealing the insignificances of the estimates of $\rho_{1}$ and $\rho_{2}$ - suggested that the adjustments of the intermediation premium and, hence, the relationship between the lending rate and deposit rate are completed in the short run. More importantly, the insignificance of the estimated coefficient $\rho_{2}$ of Equation (5) indicates that the null hypothesis $\mathrm{H} 5$ should be rejected, i.e. the Ukrainian deposit rate does not Granger cause the lending rate in the long run.

However, the estimation results of Equation (6) revealed that the estimated $\tilde{\rho}_{1}$ is statistical significance at the $1 \%$ level while the estimated $\tilde{\rho}_{2}$ is insignificant at any conventional level of significance. The finding that the estimated $\tilde{\rho}_{1}$ is statistically significant indicates that the null hypothesis $H 4$ cannot be rejected, i.e. the Ukrainian lending rate Granger causes the deposit rate in the long run.

The uses of the estimation results of the Threshold Autoregressive Vector Error-Correction model to test hypotheses 2-5 above strongly indicates that the unidirectional Granger causality from lending rate to deposit rate or the lending rate is exogenous from the deposit rate in the Ukrainian financial markets, which in turn explains the aforementioned low correlation between these two rates in both the short and long run. Moreover, the estimation results of the Threshold Autoregressive Vector Error-Correction model suggested that - when introducing the short-run dynamics to the model above the threshold - the adjustments of the intermediation premium persisted longer; but when the dynamics were below the threshold, the adjustment is completed in the short run.

The high tax rate coupled with pervasive corruption pushed a significant portion of the economy underground, which operates mostly on cash basis to avoid taxes, which leads to losses of tax revenue for the government. In turn, this not only marginalises the intermediating function of the commercial banks but also hinders the flow of foreign direct investments, as foreign companies cannot operate underground.

\section{CONCLUSIONS}

Financial intermediation or channelling funds from economic units with surpluses to economic units that need funds for profitable investments was well documented by our study as a critical facilitator for investment and economic growth. Commercial banks play a crucial role in determining the spread between the lending rate and the cost of funds or the intermediation premium. In addition to creating interest income for financial intermediaries, the spread affects the economy's savings, investments, and consumption levels. Changes in consumption or investment influence unemployment, inflation, and gross domestic product, which would improve economic development and social progress.

The research has many implications for Ukrainian economic policies. First, the test results suggest that the intermediation premium follows a stationary trend process with a structural break in July 2004, which may be attributed to the Ukrainian Central Bank's intervention to foreign exchange market in the first six months of that year.

Second, the estimation results of the TAR model revealed that the Ukrainian banks reacted in the same fashion to expansionary monetary policy as they did to contractionary policy or economic shocks that pushed the intermediation premium out of its long-run 
path. Moreover, when introducing short-run dynamics to the model, the estimation results indicated that the adjustments of the lending rate are symmetric and completed in the short run when the intermediation is either above or below the threshold.

Furthermore, the calculated partial F-statistics from the estimation of the Threshold Autoregressive Vector Error-Correction Model, reported in Table 4, revealed a unidirectional Granger-causality from the Ukrainian commercial banks' lending to the deposit rates or the exogeneity of their lending rate from their deposit rate. This exogeneity explained the low correlation of $48.31 \%$ between Ukrainian lending rate and deposit rate, which strongly indicated that lending institutions in Ukraine did not perform their intermediating responsibility effectively. This exogeneity also hinders the counter-cyclical monetary policy, investment and economic growth and, hence, social progress.

Naturally, the policy recommendation from this empirical finding is that policy-makers should seek to remove this exogeneity in the lending and deposit setting behaviour in the banking sector. Clearly, the priority of the policy should be to rectify the pervasive corruption in the economy. Unfortunately, this recommendation is much easier said than done in emerging and transitional economies, especially in Ukraine.

This empirical investigation used macro-economic data, which is a limitation, as lending and deposit rate-setting behaviours of financial intermediaries may also depend on the characteristics of the depositors, temperaments of the management of these financial institutions, borrowers, and geographical areas of the economy. Thus, a micro-based, firmlevel analysis using surveyed data of Ukrainian lending and deposit rates would be a useful complement to this study.

\section{REFERENCES}

Calem, P., \& Mester, L. (1995). Consumer behavior and the stickiness of credit card interest rates. The American Economic Review, 85, 1327-1336.

Chan, K. (1993). Consistency and Limiting Distribution of the Least Squares Estimator of a Threshold Autoregressive Model. Annals of Statistics, 21(2), 520-533.

Chang, H.L., \& Su, C.W. (2010). The lending-deposit rate relationship in eastern European countries: Evidence from the rank test for nonlinear cointegration. Czech Journal of Economics and Finance, 60, 534-544.

CIA-World Factbook (2019). Europe: Ukraine. U.S. Central Intelligence Agency. Retrieved from https://www.cia.gov/library/publications/the-world-factbook/geos/up.html on July 30, 2019.

Dueker, M.J. (2000). Are prime rate changes asymmetric?. Federal Reserve Bank of St. Louis Economic Review, 82, 33-40.

Enders, W., \& Granger, C.W.J. (1998). Unit Root Tests and Asymmetric Adjustment with an Example Using the Term Structure of Interest Rates. Journal of Business and Economic Statistics, 16(3), 304-311.

Enders, W., \& Siklos, P. (2001). Cointegration and Threshold Adjustment. Journal of Business \& Economic Statistics, 19(2), 166-176.

Hannan, T., \& Berger, A. (1991). The rigidity of prices: evidence from the banking industry. American Economic Review, 81, 938-945.

Heritage Foundation (2019). Freedom from Corruption Index-Country Rankings. Retrieved from the Global Economy https://www.theglobaleconomy.com/rankings/herit_corruption/on July 30, 2019. 
Hofmann, B., \& Mizen, P. (2004). Interest rate pass-through and monetary transmission: Evidence from individual financial institutions' retail rates. Economica, 71, 99-123. http://dx.doi.org/10.1111/ecca.2004.71.issue-281

Karagiannis, S., Panagopoulos, Y., \& Vlamis, P. (2010). Symmetric or Asymmetric Interest Rate Adjustments? Evidence from Greece, Bulgaria and Slovenia (Hellenic Observatory Papers on Greece and Southeast Europe, GreeSE Paper No 39). Retrieved from eprints.Ise.ac.uk/29168/1/GreeSE_No39.pdf on July 30, 2019.

Lim, G.C. (2001). Bank Interest Rate Adjustments: Are They Asymmetric? Economic Record, 77(237), 135-147. https://doi.org/10.1111/1475-4932.00009

McKinnon, R.I. (1973). Money and Capital in Economic Development. Washington, DC: Brookings Institute.

National Bank of Ukraine. (2005). Decision of the Council of the National Bank of Ukraine 09.09.2005 N 17. Retrieved from https://zakon.rada.gov.ua/laws/show/v0017500-05 on July 30, 2019.

Neumark, D., \& Sharpe, S. (1992). Market structure and the nature of price rigidity: Evidence from the market for consumer deposits. The Quarterly Journal of Economics, 107, 657-680. http://dx.doi.org/10.2307/2118485

Neutze, J., \& Karatnycky, A. (2017). Corruption, Democracy, and Investment in Ukraine (Policy Paper, the Atlantic Council of the United State). Retrieved from https://www.files.ethz.ch/isn/91828/Corruption_Democracy_InvestmentUkraine.pdf on July 30, 2019.

Nguyen, C.V., \& Kravchuk, A. (2019). Ukrainian Interest Rate Pass-Through in the Post-1999 Era and the Effectiveness of the Countercyclical Monetary Policy. Journal of Eastern European and Central Asian Research, 45(2), 191-204. http://dx.doi.org/10.15549/jeecar.v6i2.309

Nguyen, C.V. (2019a). Countercyclical Monetary Policy Transmission Mechanism in the U.S. and Latin American Economies over the Post-2008 Period. The International Trade Journal, 34(1), 115135. https://doi.org/10.1080/08853908.2019.1659194

Nguyen, C.V. (2019b, May 27-29). Countercyclical Monetary Policy Transmission Mechanism in the U.S. and Some Selected Transition Economies (Working Paper). International Scientific Conference on Emerging Economies in Transition, Cracow University of Economics, Krakow, Poland.

Nguyen, C.V. (2018). The Mexican Interest Rate Pass - Through in the Post U.S. Subprime Mortgage Crisis Era. The International Trade Journal, 32(1), 100-115. https://doi.org/10.1080/08853908.2017.1360226

Nguyen, C.V., Phan, D.K., \& Williams, M. (2017). The Transmission Mechanism of Russian Central Banks Countercyclical Monetary Policy since 2011: Evidence from the Interest Rate PassThrough. Journal of Eastern European and Central Asian Research, 4(2), 1-13. http://dx.doi.org/10.15549/jeecar.v4i2.165

Nguyen, C.V. (2015). The Vietnamese Lending Rate, Policy Related Rates, and Monetary Policy Post-1997 Financial Crisis. Cogent Economics and Finance, 3(1). http://dx.doi.org/10.1080/23322039.2015.1007808

Nguyen, C.V., \& Henney, S.M. (2013). Behavior of the US mortgage market following the deregulation of 1980. Journal of Business Issues, 4, 53-64.

Nguyen, C.V., \& Islam, A.M. (2010). Asymmetries in the Thai lending-deposit rate spread: An econometric analysis. Applied Economics Letters, 17, 1229-1236. http://dx.doi.org/10.1080/00036840902902201

Nguyen, C.V., Pointer, L., \& Smith, C. (2008). The asymmetric behavior of the Mexica banking interest rate margin. Journal of Business and Economics Perspectives, 34, 57-67.

Patrick, H.T. (1966). Financial Development and Economic Growth in Underdeveloped Countries. Economic Development and Cultural Change, 14(2), 174-89. 
Payne, J.E., \& Waters, G.A. (2008). Interest rate pass through and asymmetric adjustment: evidence from the federal funds rate operating target period. Applied Economics, 40(11), 1355-1362. http://doi.org/10.1080/00036840600806233

Perron, P. (1997). Further Evidence on Breaking Trend Functions in Macroeconomic Variables. Journal of Econometrics, 80, 355-385.

Rosen, R. (2002). What goes up must come down? Asymmetries and persistence in bank deposit rates. Journal of Financial Services Research, 21, 173-193. http://dx.doi.org/10.1023/A:1015085826129

Sarno, L., \& Thornton, D.L. (2003). The dynamic relationship between the federal funds rate and the Treasury bill rate: An empirical investigation. Journal of Banking and Finance, 27, 1079-1110. http://dx.doi.org/10.1016/S0378-4266 (02)00246-7

Scholnick, B. (1999). Interest rate asymmetries in long-term loan and deposit markets. Journal of Financial Services Research, 16, 5-26. http://dx.doi.org/10.1023/A:1008107030893

Schumpeter, J. A. (1912). Theorie der Wirtschaftlichen Entwicklung. Leipzig: Duncker and Humblot. Revised English translation by Redvers Opie: The Theory of Economic Development. Cambridge, MA: Harvard University Press, 1934.

Sochan, P. (1998). The Banking System in Ukraine. Russian \& East European Finance and Trade, Monetary Questions in Ukraine, 34(3), 70-93. Retrieved from https://www.jstor.org/stable/27749441 on July 30, 2019.

Stiglitz, J., \& Weiss, A. (1981). Credit rationing in markets with imperfect information. American Economic Review, 71, 393-410.

Thompson, M.A. (2006). Asymmetric Adjustment in the Prime Lending-Deposit Rate Spread. Review of Financial Economics, 15(4), 323-329.

Tkacz, G. (2001). Endogenous thresholds and tests of asymmetry in US. Prime Rate Movements. Economics Letters, 73, 207-211. 


\section{Authors}

The contribution share of authors is equal and amounted to $50 \%$ each of them.

\section{Chu V. Nguyen}

Associate Professor of Economics and Finance and former Chair of the FAEIS Department at the Marilyn Davies College of Business, University of Houston-Downtown. He earned an MA in Economics, an MS in Mathematics, and a PhD in Economics from the University of Cincinnati. $\mathrm{He}$ is the editor-in-chief of the Southeast Asian Review of Economics and Business. He is also the Chairman of the Board of Directors of Tropical Star Enterprise, Inc. He once served as an economist and then Head of the Economic Analysis and Forecasting Department at the 5th District of the US Federal Home Loan Bank System. He published over 85 publications in reputable US and international peer-reviewed journals. His research interests include monetary policy transmission mechanism, financial markets, foreign exchange rate, and issues in economic development in transitional and emerging economies.

Correspondence to: Dr. Chu V. Nguyen, Department of Finance and Management Information Systems, Marilyn Davies College of Business, University of Houston Downtown, 320 North Main Street, Suite B-444, Houston, Texas, 77002-1001, USA, e-mail: nguyenchu@uhd.edu

ORCID (i) http://orcid.org/0000-0002-7565-4047

\section{Oksana Honcharenko}

Professor of Economics. Head of the Department of Economic and social disciplines in Academy of the State Penitentiary Service. She is a deputy editor of the Scientific Journal Scientific Reviewer of Siverschyny, academician of the Academy of Sciences of Ukraine. She published over 50 publications in reputable Ukrainian and international peer-reviewed journals. She investigates the influence of external and internal factors on national economies.

Correspondence to: Dr. Oksana Honcharenko, Head of the Department of Economics, Academy of the State Peni-tentiary Service, Chernihiv, Ukraine, e-mail: oghoncharenko@gmail.com ORCID (i) http://orcid.org/0000-0001-6410-4966

\section{Copyright and License}

This article is published under the terms of the Creative Commons

Attribution - NoDerivs (CC BY-ND 4.0) License

http://creativecommons.org/licenses/by-nd/4.0/

Published by the Centre for Strategic and International Entrepreneurship - Krakow, Poland 